Meta

Journal des traducteurs

Translators' Journal

\title{
Lost in Syntax: Translating Voice in the Literary Essay
}

\section{Agnes Whitfield}

Volume 45, numéro 1, avril 2000

La traduction littéraire au Canada

Literary Translation in Canada

URI : https://id.erudit.org/iderudit/004614ar

DOI : https://doi.org/10.7202/004614ar

Aller au sommaire du numéro

Éditeur(s)

Les Presses de l'Université de Montréal

ISSN

0026-0452 (imprimé)

1492-1421 (numérique)

Découvrir la revue

\section{Citer cet article}

Whitfield, A. (2000). Lost in Syntax: Translating Voice in the Literary Essay. Meta, 45(1), 113-126. https://doi.org/10.7202/004614ar

\section{Résumé de l'article}

Cet article examine les problèmes qui se posent lors de la traduction de la voix dans l'essai littéraire. Le corpus à l'étude est composé d'ouvrages présentés aux prix du Gouverneur général en traduction (du français vers l'anglais) entre 1990 et 1995. On traite des différences de l'essai en tant que genre en anglais et en français, étant donné que ces différences jouent un rôle dans la traduction de la voix narrative. Cependant, l'article se concentre surtout sur les structures syntaxiques (structures emphatiques, ordre des mots, positionnement du sujet de la narration, etc.). Il est plus particulièrement démontré que l'incapacité de saisir l'importance de ces structures pour le sens du texte d'origine peut entraîner des glissements malheureux dans la voix des textes traduits. 


\title{
Lost in Syntax: Translating Voice in the Literary Essay
}

\author{
AGNES WHITFIELD \\ School of Translation, York University
}

\begin{abstract}
RÉSUMÉ
Cet article examine les problèmes qui se posent lors de la traduction de la voix dans l'essai littéraire. Le corpus à l'étude est composé d'ouvrages présentés aux prix du Gouverneur général en traduction (du français vers l'anglais) entre 1990 et 1995 . On traite des différences de l'essai en tant que genre en anglais et en français, étant donné que ces différences jouent un rôle dans la traduction de la voix narrative. Cependant, l'article se concentre surtout sur les structures syntaxiques (structures emphatiques, ordre des mots, positionnement du sujet de la narration, etc.). Il est plus particulièrement démontré que l'incapacité de saisir l'importance de ces structures pour le sens du texte d'origine peut entraîner des glissements malheureux dans la voix des textes traduits.
\end{abstract}

\begin{abstract}
This article will focus on difficulties in translating voice in the literary essay. The corpus examined will be taken from works submitted for the Governor-General Award in translation (French to English) between 1990 and 1995. Reference will be made to differences in this essay as genre in English and French, as these differences affect the translation of narrative voice. The primary focus of the article, however, will be on syntactic structures (emphatic structures, word order, narrative subject positioning, etc.) More specifically, it will be shown that a failure to understand the importance of these structures to the meaning of the original text can result in infelicitous shifts in voice in the translated texts.
\end{abstract}

\section{MOTS-CLÉS/KEYWORDS}

syntax, narrative voice, literary translation, Canada, literary essay

By and large, syntax does not figure very prominently in English and Frenchlanguage translation theory as an issue in translating literary texts, or any other type of text for that matter. André Lefevere's approach in Translating Literature is fairly typical. Only two pages are devoted to the topic. Why? Lefevere replies implicitly to this question at the beginning of the entry: "Syntax is the most stringent and least flexible of all the constraints translators must work under since it regulates the order of the words to be translated and because few liberties can be taken with that order before the text veers into the unintelligible" (78). This view of syntax as essentially a question of constraints at the level of the linguistic code also dominates manuals on English/French translation of pragmatic texts. While Jean Delisle, for instance, certainly delves more thoroughly than Lefevere into syntax, devoting an extensive chapter in La traduction raisonnée to the topic (247-326), he remains primarily concerned with the syntactic structures (false comparisons, negation, subordinate clauses, present participles, etc.) particular to each language, and what similar, or different, syntactic structures can be considered equivalent in the other language. 
In both cases, the strong sense of syntax as a "linguistic" given appears to preclude envisaging its "stylistic" potential, i.e. seeing syntactical structures as the result as much of choice as of obligation, and analysing how a particular variation of sentence structure and word order can contribute to meaning. Lefevere recognises this potential, but only in a general way: "Syntax affects readers by regulating not just the sequence in which they are given information and exposed to the illocutionary power of the text but also the rhythm at which both information and illocutionary power are dispensed" (78). Jean Delisle is categorically dismissive: Dans le cas des textes pragmatiques, il importe assez peu, en règle générale, que le moule syntaxique dans lequel sont coulées les idées traduites soit identique à celui de la langue originale (247). This sets the tone for the chapter, which is really about avoiding syntactical interference between French and English ${ }^{1}$.

These brief remarks are not meant in any way to diminish the considerable contribution of Lefevere or Delisle to translation theory, but rather to illustrate to what degree syntax remains underestimated, particularly in comparison with semantic issues, even by the most eminent theoreticians. Burton Raffel in The Art of Translating Prose and Paul Bensimon in a special issue of Palimpsestes devoted to word order offer two notable exceptions. Raffel makes syntax the cornerstone of prose translation: "Proper translation of prose style is absolutely essential to proper translation of prose," he declares, "and close attention to prose syntax is essential to proper translation of prose style" (x). However, the strategies he goes on to develop for "tracking syntactic movement" (17) focus predominantly on questions of sentence rhythm (rendered specifically by punctuation) and his underlying assumption that this rhythm is somehow immutable, i.e. independent of specific language constraints, is problematic. Disputing a commonly held belief that the English sentence is more dynamic than the French phrase, the contributors to Paul Bensimon's issue of Palimpsestes address a wider range of syntactic issues in translation. They explore not only how word order patterns differ between languages, but more specifically how changes in conventional word order, by creating emphasis and rhythmic effects, can contribute to meaning.

This, too, is the focus of the present article, but within the larger framework of translating voice. While many literary translators will agree that achieving the right voice in the translated text is essential, and that this is part of ensuring the artistic unity of the translation, it is not always clear how these are related, and how they are to be achieved in concrete terms. The very notion of voice is uncertain. It includes what practising translators often refer to as the mouvement of the text, its tone, its intention or the effect the author seems to be wanting to achieve on his or her reader, the particular point of view from which he or she is speaking. For the purposes of this article, I will define voice loosely as the relationship of the narrating subject to his or her own text, as this relationship is revealed through the formal characteristics of the text itself. Working within the framework of narratology or text semiotics, I use the term narrating subject here to refer not to the author of the text, but to the linguistic subject inscribed explicitly or implicitly in the text as narrator. In the same way the narrating subject is encoded in the text, so too is the textual instance, or narratee, to whom the subject addresses his or her text. ${ }^{2}$ Consequently, it is possible to work back from the formal characteristics of the text to uncover the relationship the narrating subject establishes not only with the information he or she 
is transmitting, but also with the textual instance to whom this information is being transmitted.

Two years (1992-1993) as jury member for the Governor-General's Award for translation (French into English) gave me a hitherto unprecedented opportunity to examine in detail a wide variety of literary texts, including a large number of literary essays. I was struck by how often infelicities in capturing and transmitting information in the syntax of the original text were the cause of noise in the translated text, i.e. areas where voice became unclear, blurred, less coherent than in the original.

The topic of voice is large and complex. In this article, I would like to focus on three specific phenomena: emphatic structures, text coherence and, finally, narrative subject positioning. I will look at how these phenomena manifest themselves through word order, how they contribute to the overall meaning of the text, and how they reveal and develop voice, the relationship of the narrating subject with his or her text and encoded narratee. Through examples taken from French/English translations of literary essays published in Canada between 1991 and 1993, I will demonstrate how easy it is to neglect such text phenomena in the translation process, and what negative effects this can have on the artistic unity of the translated text. As Georges Mounin has so accurately affirmed, toutes les structures n'ont pas de fonction, [...] toutes les fonctions ne sont pas pertinentes, ne sont pas esthétiquement pertinentes (38). This article looks at how syntactical structures can be and are esthetically relevant for the translator.

Given the text oriented nature of my comments, it is useful to analyse chunks of texts, rather than examples from within sentences taken in isolation. This is all the more essential since the three phenomena I will be looking at are interconnected. In fact, it is their combined contribution to voice that constitutes their force as a factor in the artistic unity of the translated text. Obviously, the detailed textual analysis required means that the number of separate examples I can comment on meaningfully here is limited. I have chosen a corpus of three texts which illustrate particularly clearly the translation difficulties I am addressing. All three are edited by McGillQueen's Press, a fact which is purely incidental, and more than anything, most probably a reflection of the importance of this Canadian press in the publication of translations of quality. While my analysis inevitably picks out areas of weakness in the translations, its fundamental goal is not to criticise these particular translations, but to explore, in a more general way, the contribution of syntax to meaning in translation.

\section{Emphatic structures}

In their well-known work on comparative stylistics, Vinay and Darbelnet distinguish between l'ordre des mots, qui est un phénomène relevant de la structure, et la démarche, qui semble être l'exploitation de certaines préférences dans la présentation des faits et qui relève, jusqu'à un certain point, de l'option (201). However, since their goal is to highlight structural differences and similarities between English and French, they use the notion of word order options to explore how sentences are generally constructed in each language as opposed to how particular stylistic effects may be achieved. Their observations are nonetheless pertinent here, because they underscore that between syntax as a grammatical constraint, and syntax as stylistic choice, there is also the 
level of conventional usage. Emphatic effects occur, as they point out, when this conventional or "normal" word order is changed. This is the case in French, as they point out, with various tours de présentation such as voici, quant à moi (209-210), the clivées françaises (Volsik: 77), as well as different forms of sentence inversion. Pierre Cadiot offers a more complex analysis, identifying four specific types of emphatic structure: l'inversion (1), le détachement sans rappel (2), la dislocation (3) et le détachement thématique (4) (20).

Thomas Kane provides a comprehensive analysis of comparable emphatic structures in English, including those that operate at the intra-sentence level, including displaced adjectives, ellipsis, isolation of a term from the other words in the sentence (295-310) and those that concern the sentence as a whole: announcement sentence, sentence fragment, imperative sentence, interrupted sentence, inverted sentence, negative-positive restatement, periodic sentence, rhetorical question, short sentence, rhythm and rhyme (280-294). While I am certainly not advocating that translators should always translate, for instance, an inversion in the Source Language, by an inversion in the Target Language, it is nonetheless clear that both languages offer a wide range of emphatic structures to choose from. Between English and French, at least, the translation of emphasis does not appear to present a basic problem, such as would be the case if the Target Language were devoid of emphatic structures.

The following passage, particularly rich in emphatic structures, is taken from the first chapter of La jeunesse sous Thermidor by Québécois historian, François Gendron:

Dans l'esprit des Parisiens, le 9 thermidor c'était la fin de la tyrannie et la tyrannie, c'était avant tout les quelque 8500 détenus des 40 prisons de Paris. D'où un vaste mouvement d'opinion qui, spontanément, se fit jour en leur faveur dans les assemblées générales du 15 thermidor, les premières après la chute de Robespierre, et où les Modérés, comprimés depuis le 31 mai, réapparurent en masse pour réclamer des mises en liberté. Ainsi, à la section des Marchés, l'assistance se trouvait «nombreuse de plus du double qu'à l'ordinaire». Même agitation dans les maisons d'arrêt pleines «d'une joie incroyable» et où fermentaient déjà les fureurs de la Réaction. Le 16 thermidor à la prison Lazare, les détenus réclamaient du vin, des commissaires et menaçaient d'égorger le concierge. Aux Anglaises, quelques jours plus tôt, c'était une clameur générale: «Les prisonniers s'imaginent que les autorités constitués qui les ont fait incarcérer vont y rentrer à leur tour et qu'ils vont prendre leur place», écrit le comité révolutionnaire de la section du Finistère le 12 thermidor. En vérité, il ne pouvait pas mieux dire. Et de continuer en expliquant que "plusieurs nouveaux visages s'étaient répandus dans le sein de notre assemblée, y portaient le trouble et demandaient la mise en liberté de tous les détenus immédiatement ».

À la convention, on commença par s'opposer à ce mouvement d'opinion dont on ne saisissait visiblement pas l'ampleur... (18)

The sections marked in bold show the numerous emphatic structures used by the author. There are several inversions, based on the displacement of an adverbial phrase, emphasising the date, or more often, the place of action. There are sentence fragments (Même agitation [...]), as well as examples of dislocation (qui, spontanément, se fit jour [...]), incises (les premières après la chute de Robespierre) and clivées (c'était la fin [...] et c'était avant tout [...] ). By their sheer numerical importance, the emphasis structures give the entire passage an energetic, engagé, tone, one of living history, rather than dry analysis. The passage begins with what Cadiot calls a détache- 
ment sans rappel (Dans l'esprit des Parisiens,) whose function here is exactly, as Cadiot indicates, to introduce:

la trace d'un mécanisme dialogique implicite: le constituant détaché est naturellement attribuable à une autre voix [...] un certain type d'interprétation thématique s'impose nécessairement (aboutness, thème au sens d'un topique: «ce à propos de quoi»). L'auditeur est pour ainsi dire contraint à interpréter ce qu'on peut aussi appeler d'un terme traditionnel l'apodose (i.e. dans ce contexte, la prédication) dans l'horizon thématique ouvert par le constituant détaché (la protase) (20-21).

The dialogic character of this initial emphatic structure clarifies, in fact, the meaning of the proliferation of emphases throughout the text. On the one hand, the reader is invited to read the passage from the point of view of the Parisians living the events. This explains the temporal, but especially the spatial references, highlighted by the inversions, as well as the clivées and the overall intensity of the passage. We are to follow the electrifying events of the French Revolution "when" but also "where" they happen. On the other hand, the instance external to the Parisian's point of view, i.e. the historian, also present in the dialogic nature of the initial reference, invites us to analyse, as well as relive. It is the historian's more analytic point of view that is underlined by the incises, some of the dislocations, the sentence fragments (which reflect an appreciation of comparison or causal effect) as well as the one, noticeably shorter sentence.

Let's look now at how the translator has handled the passage:

For Parisians, 9 Thermidor, Year II, marked the end of the "tyranny," which was symbolized, above all, by the inmates of Paris's forty prisons, some 8,500 individuals. Hence the vast movement of public opinion in their favour which spontaneously sprang up on 15 Thermidor in the first general assemblies held since the fall of Robespierre. The moderate Thermidorians, whose ranks had thinned since 31 May, returned in force to the assemblies to call for the release of the detainees. In the Marchés Section, it was reported that more than twice the usual number attended. There was similar agitation in the prisons, where the prisoners were overcome with joy at the news-and where the rage of the Reaction was already simmering. On 16 Thermidor, the inmates at the Lazare prison demanded that they be given wine and threatened to cut the warden's throat. There had been a general uproar at the Anglaises jail a few days earlier: "The prisoners think that the men in power who had them incarcerated are now going to be locked up and that they, the released prisoners, are going to take over from them," wrote the revolutionary committee of the Finistère Section. And the committee was quite right. It went on to explain that several new faces had shown up at the general assembly, "causing trouble and calling for the release of all inmates without distinction."

Initially the Convention spoke out against the demand that prisoners be released, obviously underestimating the strength of public opinion.... (6)

There is no doubt that certain characteristics of the syntax of Gendron's French text are problematic for the English-language translator. This is particularly the case for the sentence fragments, based on syntactic structures not available in English: D'où, Même agitation, Et de continuer. The same is true for the use of clivées, notably in the first sentence, where the structure also involves syntactic repetition. I point out these difficulties, to recognise the presence of linguistic constraints, and also to underscore the challenge they pose to the translator. The object of the comments that 
follow is not to criticise this particular translation, but to point out issues in translating syntactic structures.

For it is clear that the double focus of the French text, and its general engagé tone, have given way to a more distanced, more anonymous tone. In this process, information, too, has been lost. The sections in bold indicate the site of this loss. For whom, for instance, did the prisons symbolise tyranny? What is the logical connection between the spontaneous outbreak of the vast movement of public opinion in the first assemblies held since the fall of Robespierre, and the return in force of the moderate Thermidorians? Through the play-by-play spatial emphases, the original text articulates the relationship between the outbreaks in various clearly defined prisons, the mood in the assemblies, and the reaction of the Convention. It follows, and highlights (through the positioning of spontanément, for example), the strength and impact of the change in public opinion. In the English text, this relationship is obscure; the mix of spatial and temporal indicators is no longer linked to the direct experience of the events (notice also in this respect that the direct quotations of the original have been replaced by indirect discourse: "it has been reported"). This makes it more difficult for the reader to follow the argument. While the proliferation of distancing structures of a more descriptive nature ("there was") gives the translation a semblance of greater objectivity, in keeping with the point of view of the historian, the text has lost in forcefulness, and, more importantly, in analytic clarity. This is particularly evident in the translation of the one emphatic, short sentence, which, in the original, brings together the two points of view in the text: the predictive ability of the committee at the time, and the historian's verdict in hindsight. Paradoxically, it is the historian's encoded presence that disappears in the English sentence, adding further to the confusion of voice in the translation.

\section{Coherence}

"Coherence, writes Kane, belongs to the substructure of a paragraph, to the relationship of its ideas" (114). More specifically, as Jean Delisle states: la cohérence correspond à la rigueur de l'enchaînement des énoncés, à la précision des rapports logiques [...] Elle se situe sur le plan logique, conceptuel (427). Coherence can be distinguished from flow, which "appears in the surface, visible in the explicit words and in the similarities of grammatical pattern that link sentence to sentence" (Kane: 114). In this sense, flow is similar to cohesion: ce terme désigne les liens grammaticaux et lexicaux unissant les mots d'une phrase ou les phrases d'un texte (Delisle, 427).

As the analysis of Gendron's text reveals, emphatic structures clearly contribute to coherence, by highlighting the underlying logic of the text. However, word order also contributes to text coherence in other concrete ways. "Although there can be no simple correlation between word order and the way a speaker chooses to structure the information he wishes to convey, notes Keith Brown, the two matters are intimately related" (259). The concept pairs "given/new," "topic/comment" or "theme/ rheme" (Leckie-Tarry: 137-139) have been formulated by linguists to represent this relationship, by tracking how information flows in conventional sentence structures in English, from what is known by the reader, to the new information being presented: 
While the choice of Theme carries forward the development of the text, the choice of information focus (i.e. New information) expresses the main point of the information unit [...] The structure of unmarked Theme and focus creates 'a kind of diminuendo—crescendo movement' (Halliday: 316) in the typical English clause with these two complementary types of prominence. (Leckie-Tarry: 139)

Word order is also linked to text coherence in French. If we look at language not as code but as discours, "le thème n'est pas seulement connexe pour la mise en relief, il est aussi, semble-t-il, complémentaire; sera thématique en un sens tout ce qui est accessoire de mise en relief." (Cadiot: 26). "Le détachement thématique," continues Cadiot:

introduit un thème du discours, au sens clair d'une opposition thème/propos (aboutness). Sa fonction principale semble être, en s'ancrant dans le préalable, de créer une sorte de rupture dans l'enchaînement du discours, de façon à s'engager sur une voie nouvelle (26).

Like Brown, however, Cadiot cautions that the concepts of theme or "aboutness" are speculative, interpretative categories: Toutes ces notions sont, elles aussi, des sortes de reconstructions, des marquages en retour dans la langue de ce qui est immédiat dans le discours (26). In this respect, their particular function is not a constant of their form, but a reflection of their context of usage.

In comparison with the extract from Gendron, the following passage, taken from L'intolérance by Lise Noël, is relatively bereft of emphatic structures. Word order nonetheless contributes significantly to text coherence:

Les mouvements d'émancipation ne sont pas morts. Ils revêtent simplement une forme différente de celle qu'ils avaient prise dans les années 1960 et 1970. Si l'heure n'est plus aux vastes élans contestataires et aux grandes synthèses critiques, la lutte pour la tolérance se poursuit à travers les recherches patientes et les interventions ciblées.

On ne compte plus en effet les groupements qui travaillent à l'amélioration du sort des individus et des communautés démunis ou victimes d'abus. Les études historiques et sociologiques sur des catégories spécifiques d'opprimés ou sur la dynamique générale des rapports de domination se font aussi de plus en plus nombreuses et sortent autant des presses universitaires que des maisons d'édition parallèles.

Pour être plus modestes, les aspirations qui marquent ces entreprises n'en sont pas moins radicales, car les résultats conjugués auxquels pourraient donner lieu ces efforts apparemment isolés ne sauraient manquer de transformer la société en profondeur. Cette transformation ne devrait pas toutefois être le simple produit d'un effet mécanique. Il est évident que, partout, désormais, les groupes de libération expriment la volonté des dominés d'accéder au pouvoir: pouvoir de dire, mais aussi pouvoir de faire. Or cette quête marque autant le point d'aboutissement du processus de libération amorcé dans les années 1960 que la nécessité d'enclencher la résistance aux conservatismes actuels. (9)

What is striking in this text (where I have again marked in bold the emphatic structures) is the systematic usage of the theme/rheme sentence structure. The logical connection between each idea presented is reflected in the movement between clauses within each sentence, from the given to the new, as well as between sentences, each additional sentence starting out with a backward glance to the preceding sentence. The sentence configurations are stubbornly assertive, lending a gravity to the clearly persuasive intention of the text. The exact tone, however, is difficult to place. 
Is this effect of gravity an indication of the didactic nature of the text? Or does it relate to the seriousness of the subject?

The answer to these questions becomes clearer at the beginning of the third paragraph. The pattern of theme/rheme assertive sentences is maintained (plus modestes can be seen to qualify the aspirations of all the entreprises described in the second paragraph), but superimposed on this pattern is a series of emphatic structures. The initial inversion highlights the presence of an implied criticism, or counter argument, to which the heavy assertiveness of the narrating subject is, in fact, a response. Moreover, this point/counterpoint formulation (plus modestes [...] moins radicales) underlies the other emphatic structures in the paragraph (pouvoir de dire, pouvoir de faire; autant $[. .$.$] que [\ldots])$. Clearly, the tone can no longer be associated only with the didactic nature of the text; rather it reveals the narrating subject's concern with and strongly felt need to refute what she perceives as implicitly present and pervasively held counter arguments. This commitment, in the French sense of engagement is further accentuated, in the same third paragraph, by the appearance of the modal verb of moral obligation, devrait.

Here is Arnold Bennett's translation:

Movements of emancipation are not dead. They have simply taken on a form different from the one they had in the 1960s and 1970s. Though the time of vast anti-authoritarian revolt and global critical syntheses may have passed, the struggle for tolerance goes on through patient research and specifically focused action.

Countless organisations are working to improve the lot of communities and individuals who are underprivileged or victims of abuse. Historical and sociological studies of specific oppressed groups or of the general dynamics of domination are also emerging in ever greater number, from both university presses and mainstream publishers as well as from small presses.

Though the aspirations which are the hallmark of these ventures are more modest, they are no less radical, since the combined results of these apparently isolated effects cannot fail to bring about a profound transformation of society. But this transformation will not come about mechanically. Liberation groups everywhere now clearly express a desire to attain not only the power to speak but the power to do things. This quest, the culmination of the liberation process launched in the 1960s, is also made necessary by the need to set in motion resistance to current forms of conservatism. (3)

In the first two paragraphs, Arnold Bennett is relatively faithful to the initial syntax, by and large maintaining the theme/rheme word order pattern, and coherence is maintained. It is in the third paragraph, with the accumulation in French of emphatic structures, that the translation bogs down. At the beginning of the paragraph, for instance, the displacement of "more modest" towards the middle of the sentence, obscures its relationship to the preceding paragraph, its value as "theme." We no longer have the sense that the comments here refer back in fact to all the more modest ventures of the second paragraph. The intra-sentence contrast is respected, but the change in word order affects the underlying logic of the argumentation. Furthermore, in the French text, the argument/counter argument contrasts contribute to this logic, by situating the objectives and intention of the narrating voice. In the translation, the play of contrast no longer works with the text logic, but against it. This is particularly true in the last three sentences of the paragraph, with the introduction of "But" in an emphatic position, displacing the theme, the de-emphasis of "everywhere now" (compared to the inversion in French), and the elimination of the 
contrast structure (autant [...] que). As a result, the argument becomes fuzzy. What does "merely mechanical" mean? It becomes much more difficult to follow the arguments of the text; the tone of the text remains descriptive, but loses in energy and focus. The translation loses in coherence.

\section{Subject positioning or perspective}

"If we define 'topic' as what the sentence is about," states Brown, "then 'perspective' may be considered to be the point from which the topic is to be viewed" (260). This encoded point of view is clearly an important component of the relationship the narrating subject constructs with his or her text and narratee. Such is its importance, that I have not been able to avoid referring to this level of text interpretation to explain the discursive functions of the emphatic structures and text coherence patterns we have already examined. However, these are not the only syntactical manifestations of perspective. As Brown points out:

although active and passive sentences paraphrase each other, they do not always have the same distribution; we might, indeed, consider part of the function of the passive form to relate to the speaker's ability to choose to make a non-agentive NP subject, or to avoid mention of the agent altogether, or both. (257)

Similarly, the choice of sentence type (assertive, imperative or interrogative), the use of direct or indirect discourse and sentence complexity (simple, compound, or complex) can also reveal the point of view of the narrating subject. Kerbrat-Orecchioni examines a wide range of lexical and morphological choices which also reveal subject positioning: temporal and spatial localisation, evaluative or affective adjectives and adverbs, demonstrative pronouns, shifters, etc. (34-120). But our concern here is with syntax.

George Sioui's book, Pour une autohistoire amérindienne, provides an excellent example here, for the very title raises explicitly the question of subject positioning. In this autobiographical book, the author is assuming a direct relationship with the narrating subject. The following passage is taken from the introduction:

Triste et confus, je repris le chemin de l'école à la maison, après avoir reçu ma première leçon d'histoire du Canada. J'avais six ans et je commençais la troisième année du primaire, enfant de réserve indienne, de famille à revenu moins que moyen, dont la conscience et la fierté amérindiennes étaient particulièrement marquées.

«Vos ancêtres, avait dit l'imposante mère supérieure chargée de la classe d'histoire, étaient des Sauvages qui n'avaient pas la connaissance de Dieu. Ils étaient ignorants et insouciants de leur salut. » Puis, avec une sincérité qui l'amenait par moments au bord des larmes: «Le roi de France en eut pitié et leur envoya des missionnaires qui ont essayé de les convertir, mais vos ancêtres, les Sauvages, ont tué ces missionnaires qui sont devenus les saints martyrs canadiens. Grâce à Dieu et à son Église, vous êtes aujourd'hui devenus des gens civilisés. Chaque jour, vous devez demander pardon à Dieu pour les péchés de vos ancêtres et Le remercier de vous avoir fait connaître la foi catholique, de vous avoir arrachés aux mains du diable qui maintenait vos aïeux dans une existence d'idolâtrie, de vol, de mensonge et de cannibalisme. Mettez-vous à genoux maintenant, nous allons prier pour les saints martyrs canadiens. »

Un tel récit semblera familier à la plupart des gens qui ont grandi et vécu dans une partie ou l'autre des Amériques. Mais par sa familiarité, voire sa banalité, c'est que très peu d'Euro-Américains (sur tout le continent) auront imaginé, avec la sympathie 
normale chez les humains, les effets dévastateurs d'un tel enseignement sur le développement de jeunes esprits de nombreuses générations successives et, de ce fait, sur leurs chances de contribuer dignement à l'avancement de la science humaine. De la même manière, peu d'Euro-Américains, lorsqu'ils font face à la réalité sociale amérindienne, ressentent spontanément une responsabilité d'aide. (1-2)

In these three paragraphs where I have again marked in bold the emphatic structures, Georges Sioui sets out clearly the fundamental power relationship underlying his personal and professional desire for an Amerindian autohistory. The first two paragraphs recount the experience of the narrating subject as a child. The personal nature of this experience and its negative impact are highlighted by a number of syntactical choices. The emphatic structure at the beginning of the first sentence in the initial paragraph stresses the feelings of the author as a child. The use of direct discourse underlines the immediacy and the intensity of the ideological aggression experienced by the author as young child, downcast, confused and shamed. The use of incises in the first sentence of the second paragraph underscores the powerful presence of the mother superior, in the eyes of the young child. In this context, the declarative verb avait dit takes on the solemn connotations of the biblical reference to the word as law.

Throughout these paragraphs, however, the double positioning of the author does not vary. In keeping with the duality inherent in the word "autohistory," the author as historian carries the narration, while relating the story of his own childhood. This is evident in the use of the preterit in the first sentence, as well as in the descriptive passages in the first paragraph, and to a lesser degree in the second, where, in a non judgmental fashion, the narrator provides his own reader, or narratee, with a context (information on the family income and values, description of the sincerity of the mother superior) for interpreting the incident.

Curiously, after setting out this harsh reality, the third paragraph appears the least direct, or certainly the most complex, in its subject positioning, particularly with respect to the relationship between the narrating subject and his narratee. With respect to the latter, the function of the initial emotional references to (replay of) a painful childhood experience would seem to be at once to shock and move the narratee, who is evidently a non Amerindian. In the third paragraph, the author looks in a seemingly more impersonal way at how present-day Euroamericans remain abysmally unaware of the impact of such a version of history on Amerindian people. While the logic of the text implies that the narratee belongs in fact to this group of unaware Euroamericans, the author does not make this implicit. The relationship between narrator and narratee is distanced (from an implicit "you" to an explicit "they"), through the more "objective" viewpoint of the historian. At the same time, the more personal, or emotional, commitment of the author resurfaces in the intra-sentence emphatic structures: the tour de présentation (mais ce qui devrait également frapper) and the two examples of incises (voire sa banalité, avec la sympathie normal...).

How is this dual subject positioning handled in the translation? Here is the English version by Sheila Fischman:

Sad and confused, I headed home from school, having just received my first lesson in Canadian history. At the age of six I was starting my third year of primary school: a 
child from an Indian reservation, whose family had a below-average income but a strong Amerindian consciousness and pride.

"Your ancestors," said the imposing mother superior who taught us history, "were savages with no knowledge of God. They were ignorant and cared nothing about their salvation." And then, with a sincerity that sometimes had her close to tears: The king of France took pity on them and sent missionaries who tried to convert them, but your ancestors, the savages, killed those missionaries, who became the blessed Canadian martyrs. Now, thanks to God and His Church, you are civilized people. You must ask God's pardon every day for the sins of your ancestors, and thank Him for introducing you to the Catholic faith, for snatching you from the hands of the Devil who kept your ancestors in a life of idolatry, theft, lying, and cannibalism. Now get down on your knees, we're going to pray to the blessed Canadian martyrs."

The story will be familiar to most people who have grown up and lived in some part of the American continent. But what should be equally familiar, even banal—and is not-is the fact that very few Euroamericans, anywhere on the continent, have had the common decency to imagine how devastating such teaching has been to the development of generations of young minds, and thus on their chances of making a dignified contribution to the advancement of human society. Similarly, few Euroamericans, when faced with the Amerindian social reality, feel any spontaneous responsibility to help. (xix-xx)

Through a number of infelicitous syntactical and lexical choices, the two subject positions of the narrator are confused. While the French text separates the child from the historian, insisting on the immediacy of the experience of the six-year-old as illustrative of the analytic point the historian will go on to make, the English text offers the illustration as simple narrative. The causal relationship, pointed out by the historian as narrator, between the confusion and humiliation felt by the child and the history lesson is attenuated, by the choice of temporal structures ("having just" 'at the age of six") which make the child the narrating voice. The age of the child is no longer related to the humiliation, a fact important for the shock value of the story for the narratee, but to the simple descriptive fact that he was in grade three. A value judgement is introduced in the form of a contrast between the poverty of the family and their Amerindian pride. In the second paragraph, the translation of "avait dit" by the simple "said," although kept in an emphatic position, nonetheless weakens the impact of the nun's discourse. Again the causal relationship between the words of the mother superior and the child's humiliation, and the abusive power structure it illustrates, is attenuated. One could also comment on the lexical choices at the end of this paragraph ("snatch" for avoir arrachés, the more familiar "get down on your knees," and the contraction "we're") which again situate the story in the land of less serious children's stories, as opposed to the context of institutionalised violence portrayed by the historian as autohistorian.

This deconstruction of the author's subject positioning, at the expense of the effect he is clearly aiming for in the narratee, is even more striking in the translation of the third paragraph. The more distanced point of view of the historian is accentuated, while the intra-sentence emphatic structures stressing the emotional stance of the autohistorian are reduced, or simply eliminated. Un tel récit becomes "the story," the sense of frapper in the emphatic structure ce qui devrait frapper is suppressed, and the value judgment emphasised by the incise, avec la sympathie normale chez les humains becomes the more neutral "common decency." This same distancing is 
reflected in the translation of the site specific terms de ce fait by the more abstract, less engaged word, "thus," while the implicit identification of the autohistorian with today's young Amerindians, reflected in the adverb dignement is now associated with the more distanced "dignified contribution."

\section{Conclusion}

The above examples clearly illustrate the importance of appropriately decoding the importance of source language syntactical structures in representing voice. Rather than simple reflections of source language linguistic constraints, these structures are essential clues to the relationship the subject constructs both with the information he or she is presenting, and with the narratee he or she is aiming to influence. In all three examples, failure to respect the function (as opposed to the form) of these particular syntactical choices has led to problems in coherence and unity of voice. The tone of the original has been lost, the underlying argument of the text has become more obscure, and the artistic unity of the text has been undermined.

How can one explain the infelicities in the translations we have examined? My initial argument concerns the failure of translation theory to address syntactical issues. More specifically, a stringently normative view of sentence construction can work against a translator's ability to recognise and respect emphatic structures. If we hold strongly to the view, expressed categorically by Hélène Chuquet and Michel Paillard, that syntax is a question not of simples variantes stylistiques mais, plus fondamentalement, de la stratégie propre à chaque langue dans l'orientation de l'énoncé dans son ensemble (135) and believe that C'est le respect des schémas dominants à ce niveau, avant même le détail des choix lexicaux ou grammaticaux, qui donne à une traduction son caractère authentique dans la langue d'arrivée (135), it is unlikely that we will devote much energy to analysing the intents and effects of syntactical choices.

It is also possible that the infelicities we have seen are a reaction to translation difficulties, i.e., situations where the particular Source Language structures do not have a simple equivalent in the Target Language. This was certainly the case with the syntactical structures of the sentence fragments in Gendron's text, and the particular uses of the French preterit (je repris) in Sioui's text.

To what degree are the infelicities we have analysed due to the constraints of the literary genre? Is the English-language essay, par définition, more distanced? Can generic conventions in the Target Language work against certain types of voice? While this may be true, the examples we have analysed suggest that assuming too often that this is necessarily the case, can easily, like the over-emphasis on syntax as linguistic constraint, lead to the dismissal of syntactic effects. For we have seen that it is not so much the move to a more distanced point of view, but the incoherent application of this strategy, which results in inconsistencies of voice, and incoherence, in the translated text. Finally, one may ask if socio-cultural constraints also push the translator towards underestimating the effects of syntactical choice? As Annie Brisset observes:

Au-delà même de l'organisation rhétorique du texte, il existe un autre type d'ordonnancement, l'ordonnancement topique. Celui-ci recouvre la manière dont une société privilégie certains mots et les organise en propositions, argumentations et récits pour représenter les réalités qui la concernent. Cette représentation, médiatisée par l'imaginaire collectif, est d'ordre symbolique. (113) 
This implicit power of the socio-cultural values of the Target Language to deflect, displace, or even eliminate certains aspects of voice in the Source Language text, might well explain why Sheila Fischman reintroduces an opposition between the poverty of Sioui's family and their family pride, and generally underplays the shock value of the childhood experience recounted by George Sioui. While all three factors may explain why dealing with syntax is problematic for translators, they also reinforce the necessity for translation theory to address these questions more thoroughly.

\section{NOTES}

1. This is also the position of Claude and Jean Demanuelli: Le respect des idiosyncrasies syntaxiques de la rhétorique-source n'est pas facilité par la divergence des démarches adoptées par les langues en présence en matière d'ordre canonique et de mise en relief. Composer avec l'écriture originale du texte de départ, c'est aussi, et peut-être d'abord, composer avec les contraintes de langue de part et d'autre (Lire et traduire, Paris/Milan/Barcelone/Bonn, Masson, 1991, 26). An important, if not dominant concern for them as well is the avoidance of linguistic interference: On se gardera de résoudre les problèmes posés par l'ordre des mots en ayant recours au calque (27).

2. For further information on the relationship between narrator and narratee, and the general issue of text subjectivity, see Catherine Kerbrat-Orecchioni, L'Énonciation. De la subjectivité dans le langage, Paris, Armand Colin, 1993.

\section{REFERENCES}

\section{Theoretical References}

Bensimon, Paul (ed.) (1993): "L'ordre des mots," Palimpsestes, 7.

Brisset, Annie (1993): "L'autorité du discours social dans la traduction," Palimpsestes, 7, pp. 111132.

Brown, Keith (1984): Linguistics Today, Suffolk, Fontana Paperbacks.

Саdiot, Pierre (1991): "Le thème comme synecdoque," Palimpsestes, 5, pp. 19-36.

Chuquet, Hélène and Michel Paillard (1989): Approche linguistique des problèmes de traduction anglais/français, Paris, Ophrys.

Halliday, M. A. K (1985): An Introduction to Functional Grammar, London, Edward Arnold.

Kane, Thomas (1983): The Oxford Guide to Writing, New York and Oxford, Oxford University Press.

Leckie-Tarry, Helen (1995): Language and Context, London and New York, Pinter.

Lefevere, André (1992): Translating Literature Practice and Theory in a Comparative Literature Context, New York, The Modern Language Association of America.

Mounin, Georges (1994): Travaux pratiques de sémiologie générale. Textes réunis et publiés par Alain Baudot et Claude Tatilon, Préface de Claude Tatilon, Toronto, Éditions du GREF.

Raffel, Burton (1994): The Art of Translating Prose, University Park (Penn.), Pennsylvania State University Press.

VINAY, Jean-Paul and Jean Darbelnet (1977): Stylistique comparée du français et de l'anglais, Montréal, Éditions Beauchemin Ltée.

Volsıк, Paul (1991): "La traduction des clivées et le problème de la mise en relief," Palimpsestes, 5, pp. 77-99.

\section{Corpus}

Gendron, François (1983): La Jeunesse sous Thermidor, Paris, Presses universitaires de France.

Gendron, François (1993): The Gilded Youth of Thermidor, tr. by James Cookson, Montreal and Kingston, McGill-Queen's University Press.

NoËL, Lise (1991): L’Intolérance. Une problématique générale, Montréal, Boréal. 
NoËL, Lise (1994): Intolerance. A General Survey, tr. by Arnold Bennett, Montreal and Kingston, McGill-Queen's University Press.

Sioui, Georges E. (1989): Pour une autohistoire amérindienne, Québec, Presses de l'Université Laval.

Sioui, Georges E. (1992): For an Amerindian Autohistory, tr. by Sheila Fischman, Montreal and Kingston, McGill-Queen's University Press. 